\section{The association between gastro-oesophageal reflux disease and asthma: a systematic review}

\author{
B D Havemann, C A Henderson, H B El-Serag
}

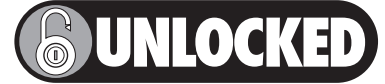

This paper is freely available online under the BMJ Journals unlocked scheme, see http://gut.bmj.com/info/unlocked.dtl
See end of article for authors' affiliations

Correspondence to: $\mathrm{H}$ B El-Serag,

Gastroenterology and Health Services Research Sections, Michael E DeBakey VA Medical Center and Baylor College of Medicine, Houston, Texas, USA; hasheme@bcm.tmc.edu

Revised 12 July 2007 Accepted 15 July 2007 Published Online First 6 August 2007
Background and aim: Gastro-oesophageal reflux disease (GORD) has been linked to a number of extraesophageal symptoms and disorders, primarily in the respiratory tract. This systematic review aimed to provide an estimate of the strength and direction of the association between GORD and asthma.

Methods: Studies that assessed the prevalence or incidence of GORD in individuals with asthma, or of asthma in individuals with GORD, were identified in Medline and EMBASE via a systematic search strategy.

Results: Twenty-eight studies met the selection criteria. The sample size weighted average prevalence of GORD symptoms in asthma patients was $59.2 \%$, whereas in controls it was $38.1 \%$. In patients with asthma, the average prevalence of abnormal oesophageal $\mathrm{pH}$, oesophagitis and hiatal hernia was $50.9 \%, 37.3 \%$ and $51.2 \%$, respectively. The average prevalence of asthma in individuals with GORD was $4.6 \%$, whereas in controls it was $3.9 \%$. Pooling the odds ratios gave an overall ratio of $5.5(95 \% \mathrm{Cl} 1.9-15.8)$ for studies reporting the prevalence of GORD symptoms in individuals with asthma, and $2.3(95 \% \mathrm{Cl} 1.8-2.8)$ for those studies measuring the prevalence of asthma in GORD. One longitudinal study showed a significant association between a diagnosis of asthma and a subsequent diagnosis of GORD (relative risk 1.5; $95 \% \mathrm{Cl}$ 1.2-1.8), whereas the two studies that assessed whether GORD precedes asthma gave inconsistent results. The severity-response relationship was examined in only nine studies, with inconsistent findings.

Conclusions: This systematic review indicates that there is a significant association between GORD and asthma, but a paucity of data on the direction of causality.
G astro-oesophageal reflux disease (GORD) develops when the reflux of stomach contents into the oesophagus causes chronic troublesome symptoms or complications. ${ }^{1}$ The most recognisable symptoms of GORD are heartburn and acid regurgitation, but the reflux of noxious material may have wider-reaching effects. In addition to the well-established oesophageal complications associated with the disease, ${ }^{2}$ GORD is believed to lead to extra-oesophageal symptoms and complications, primarily in the respiratory tract. ${ }^{3}$ An association between GORD and asthma has been accepted for many years, and has been the focus of numerous studies and reviews. ${ }^{45}$ Asthma could arise as a result of acid reflux via two possible mechanisms: damage to the pulmonary tree after direct exposure to acid refluxate (reflux theory); or through bronchial constriction as a result of the stimulation of vagal nerve endings in the oesophagus (reflex theory). ${ }^{6}$ In addition, cough and increased respiratory effort may exacerbate GORD by bringing about an increased pressure gradient across the lower oesophageal sphincter. ${ }^{7}$ This could have particular relevance in patients with hiatus hernia, as gastro-oesophageal junction competence is compromised by hiatus hernia during intraabdominal pressure increases. ${ }^{8}$

The aim of this systematic review is to provide a realistic estimate of the strength and direction of the association between GORD and asthma in adults. Despite the large number of publications examining the clinical and epidemiological nature of this association, ambiguity remains. For example, estimates of the prevalence of GORD in individuals with asthma vary from $30 \%$ to $90 \% .^{9}$ A particular challenge is that the prevalence of GORD has been measured in a number of different ways in the literature. First, symptom frequency and/or severity have been used as a measure of disease. This is a patient-focused method that can be used in large population-based surveys, but a definitive symptom cutoff point for disease has not yet been established. At least weekly heartburn and/or acid regurgitation is known to impair quality of life, ${ }^{10}$ and this definition has been used in a recent systematic review, ${ }^{11}$ which reported that $10-20 \%$ of the population in the western world have GORD. Oesophageal $\mathrm{pH}$ monitoring is a more objective way of measuring abnormal acid reflux, but its diagnostic accuracy is modest. ${ }^{12}{ }^{13}$ Endoscopy is an objective way of examining for the presence of oesophagitis, but it cannot distinguish microscopic changes in the oesophageal mucosa that may underlie symptoms in some individuals. Erosive oesophagitis is present in approximately $20-40 \%$ of individuals with GORD. ${ }^{14-16}$

We have therefore chosen to review all of these different methodologies to gain a realistic picture of the association between the two diseases. We examined studies that assess the prevalence or incidence of GORD in individuals with asthma, and the prevalence or incidence of asthma in individuals with GORD. We have employed an epidemiological framework for causality that assesses the strength of association, the consistency of association, the temporal association between GORD and asthma, and finally, the severity-response association between the two diseases.

\section{METHODS}

\section{Search strategy}

Studies published between 1966 and October 2006 were identified in Medline and EMBASE using the following combinations of search terms: 'asthma and reflux' and 'asthma and (reflux or GER or oesophagitis or hiatal hernia) and (risk or odds or incidence or prevalence)'. There was no language restriction imposed on the search. Articles that potentially

Abbreviations: ATS, American Thoracic Society; GORD, gastrooesophageal reflux disease 
assessed the prevalence or incidence of reflux symptoms, abnormal oesophageal acid exposure, oesophagitis, hiatal hernia or Barrett's oesophagus in adults with asthma, or the prevalence of asthma among adults with reflux symptoms or abnormal acid exposure were selected first based on the title, and then based on the abstract. Translations of relevant nonEnglish language studies were obtained. Two independent investigators conducted the search and data abstraction.

\section{Study selection}

We sought to ensure as far as possible that the true prevalence of asthma was recorded. Studies conducted in a primary or secondary care setting were required to define asthma in accordance with American Thoracic Society (ATS) guidelines. ${ }^{17}$ Patients were therefore required to have the following: a previous diagnosis of asthma with a history of discrete attacks of wheezing, coughing or dyspnoea, and either an increase in the forced expiratory volume in one second $\left(\mathrm{FEV}_{1}\right)$ of $20 \%$ from baseline after bronchodilator administration, or a decrease in $\mathrm{FEV}_{1}$ of $20 \%$ after methacholine bronchoprovocation. ${ }^{17}$ For population-based surveys or studies that included large administrative datasets, the definition of asthma did not need to meet the ATS guidelines. Studies describing the prevalence of reflux symptoms were required to give a description of the symptoms, including their severity and/or frequency. Studies that monitored oesophageal $\mathrm{pH}$ were excluded if the monitoring was performed for less than 24 hours. Studies were also excluded if the study cohorts were composed entirely of asthmatic patients referred for suspected GORD, or if the population source was not defined. Studies were excluded if they had a sample size of less than 50 .

\section{Tabulation of results}

The full papers from the studies selected based on the content of their abstracts were analysed. A standardised abstraction form, constructed a priori, was used. The following data were collected: sampling frame, study design, sample size, control groups (if any), definition of asthma, definition of reflux symptoms, parameters for interpreting 24 hour $\mathrm{pH}$ study results, endoscopic findings, number of patients on medications for asthma and/or GORD, severity of asthma or GORD, and temporal relationships between the development of these conditions.

\section{Analysis}

We determined overall prevalence estimates by pooling values from studies meeting the selection criteria and calculating average values weighted by sample size. For the studies reporting reflux symptoms, the average prevalence was calculated both with and without the studies reporting less frequent than weekly heartburn and/or acid regurgitation. Unadjusted odds ratios were pooled from studies that had included a comparison group to give overall estimates of the association between GORD and asthma. Heterogeneity was calculated using the $\mathrm{I}^{2}$ test. $\mathrm{I}^{2}$ is the percentage of total variation across studies caused by heterogeneity. ${ }^{18}$ Severity-response and temporal relationships were also identified and presented. Publication bias was examined by constructing funnel plots of the prevalence values from the included studies, which were tested for asymmetry using Macaskill's test and the test proposed by Peters et al. ${ }^{19}$

\section{RESULTS}

In total, 65 relevant studies were identified, and 28 of these met our inclusion and exclusion criteria. The progression of studies through the search and selection process is illustrated in fig 1 , and the number of studies in each subject area is shown in fig 2 . Funnel plots indicate the absence of publication bias or a small study effect among the studies reporting the prevalence of GORD in asthma (Macaskill's $\mathrm{p}=0.2461$, modified Macaskill's $\mathrm{p}=0.80$; fig 3 ) and the presence of a possible small study effect among the studies of asthma in GORD (Macaskill's $\mathrm{p}=0.002$, Peters' $p=0.28$; fig 4 ). One study reported both the incidence of GORD in patients with asthma, and the incidence of asthma in patients with GORD. Several studies reported prevalence estimates for reflux symptoms, abnormal oesophageal $\mathrm{pH}$ and endoscopic findings, making the total number of prevalence estimates higher than the total number of studies. Only studies in adults were selected, but a minority of the studies also included some children, ${ }^{20}{ }^{21}$ and in some studies a lower age limit was not reported. ${ }^{22-27}$ In most of the included studies, the ratio of men to women was reasonably even (32-62\% men). In one study, only $12 \%$ of the study population was male, ${ }^{28}$ and in several studies over $90 \%$ of the population was male. ${ }^{29-33}$

\section{Symptoms of GORD in patients with asthma}

We identified a total of 22 studies that reported the presence of symptoms of GORD in patients with asthma. Eight studies satisfied our criteria, and are detailed in table $1^{20-22} 282934-36$ Fourteen studies were excluded from the analysis, as described in table 2.23 24 37-48 Among the included studies, one was based on a large primary care administrative database and seven were performed in secondary care settings (table 1). Most of the studies were cross-sectional $(n=7)$, whereas the database study was a longitudinal cohort study with nested case-control analysis. The pooled sample-size weighted average prevalence of GORD in asthma from the seven cross-sectional studies was $59.2 \%$. The Montreal definition of GORD recommends that moderate heartburn and/or regurgitation at least weekly should be used as a cutoff point for disease in epidemiological studies, ${ }^{1}$ and this has been employed in a recent systematic review. ${ }^{11}$ When we only included those studies that reported the prevalence of at least weekly heartburn and/or acid regurgitation $(\mathrm{n}=5)$, the average prevalence of GORD was $58.4 \%$. Three studies reported the prevalence of GORD in controls, with an average prevalence of $38.1 \%$. Pooling the odds ratios from these studies gave an overall odds ratio of 5.45 (95\% CI 1.89-15.76). At least $90 \%$ of patients with asthma used bronchodilators in the three studies in which this was reported. ${ }^{22} 2935$ In the cohort study based on a large UK primary care database, the current use of oral or inhaled steroids was associated with a nonsignificant increased risk of GORD. ${ }^{20}$

Two studies of symptoms of GORD in patients with asthma warrant particular attention. By far the largest study was the cohort study by Ruigomez and colleagues, ${ }^{20}$ which measured the occurrence of a new diagnosis of GORD in UK primary care patients. The authors found a significantly higher incidence rate for GORD (eight cases per 1000 person-years; 95\% CI 7.09.1) in those with a previous diagnosis of asthma than in controls (4.4 cases per 1000 person-years; 95\% CI 3.9-5.0), indicating that patients with asthma were 1.8 times more likely to develop GORD than those without asthma. ${ }^{20}$ The second study of particular interest aimed to avoid bias by using a strictly consecutive recruitment protocol, excluding any patients who were referred to the study by other clinicians because of gastrointestinal symptoms. ${ }^{29}$ That study found a significantly higher prevalence of symptoms of GORD in patients with asthma compared with controls without asthma (OR 2.4; 95\% CI 1.6-3.6)..$^{29}$ Asthma severity was directly related to the age of onset of reflux symptoms. ${ }^{29}$

\section{Studies that monitored oesophageal $\mathrm{pH}$ in patients with asthma}

We identified 32 studies in which oesophageal pH monitoring was performed in patients with asthma. Nine studies were 
Table 1 Included studies reporting the prevalence of reflux symptoms in individuals with asthma

\begin{tabular}{|c|c|c|c|c|c|c|c|c|c|c|}
\hline \multirow[b]{2}{*}{ Reference } & \multirow[b]{2}{*}{ Country } & \multirow[b]{2}{*}{ Study design } & \multirow[b]{2}{*}{ Patient recruitment } & \multirow{2}{*}{$\begin{array}{l}\text { Population } \\
\text { source }\end{array}$} & \multirow{2}{*}{$\begin{array}{l}\text { Definition of reflux } \\
\text { symptoms }\end{array}$} & \multirow{2}{*}{$\begin{array}{l}\text { Method of data } \\
\text { collection }\end{array}$} & \multirow{2}{*}{$\begin{array}{l}\text { Prevalence or } \\
\text { incidence of reflux } \\
\text { symptoms in patients } \\
\text { with asthma (\%) }\end{array}$} & \multirow{2}{*}{$\begin{array}{l}\text { Prevalence of } \\
\text { reflux symptoms } \\
\text { in controls (\%) }\end{array}$} & \multicolumn{2}{|c|}{ Odds ratio/relative risk $(95 \% \mathrm{Cl})$} \\
\hline & & & & & & & & & Unadjusted & Adjusted \\
\hline $\begin{array}{l}\text { Field et al } \\
1996^{22}\end{array}$ & Canada & $\begin{array}{l}\text { Cross- } \\
\text { sectional }\end{array}$ & Consecutive & $\begin{array}{l}\text { Secondary care, } \\
\text { asthma clinic }\end{array}$ & , Heartburn in past week & Questionnaire & $49 * / 109(45.0 \%)$ & $7^{*} / 68(10.3 \%)+$ & $\begin{array}{l}\text { OR } 7.1 \\
(3.0 \text { to } 17.0) \neq\end{array}$ & - \\
\hline $\begin{array}{l}\text { Carmona- } \\
\text { Sanchez et al } \\
1999^{28}\end{array}$ & Mexico & $\begin{array}{l}\text { Cross- } \\
\text { sectional }\end{array}$ & Consecutive & $\begin{array}{l}\text { Secondary care, } \\
\text { asthma clinic }\end{array}$ & $\begin{array}{l}\text { Heartburn twice weekly } \\
\text { for } 3 \text { months }\end{array}$ & Questionnaire & $30 / 60(50.0 \%)$ & - & - & - \\
\hline $\begin{array}{l}\text { Compte et al } \\
2000^{34}\end{array}$ & Spain & $\begin{array}{l}\text { Cross- } \\
\text { sectional }\end{array}$ & Consecutive & $\begin{array}{l}\text { Secondary care, } \\
\text { asthma clinic }\end{array}$ & $\begin{array}{l}\text { Any heartburn, acid } \\
\text { regurgitation or } \\
\text { dysphagia in past } 6 \text { weeks }\end{array}$ & Questionnaire & $40 / 81(49.4 \%)$ & - & - & - \\
\hline $\begin{array}{l}\text { Gatto et al } \\
2000^{21}\end{array}$ & Italy & $\begin{array}{l}\text { Cross- } \\
\text { sectional }\end{array}$ & Consecutive & $\begin{array}{l}\text { Secondary care, } \\
\text { asthma clinic }\end{array}$ & $\begin{array}{l}\text { Heartburn and/or acid } \\
\text { regurgitation at least twice } \\
\text { weekly }\end{array}$ & Questionnaire & $51 / 100(51.0 \%)$ & - & - & - \\
\hline $\begin{array}{l}\text { Sontag et al } \\
2004^{29}\end{array}$ & USA & $\begin{array}{l}\text { Cross- } \\
\text { sectional }\end{array}$ & Consecutive & $\begin{array}{l}\text { Secondary care, } \\
\text { asthma clinic }\end{array}$ & $\begin{array}{l}\text { Heartburn twice weekly } \\
\text { for } 1 \text { year }\end{array}$ & Personal interview & $185 \ddagger / 261(71.0 \%)$ & $\begin{array}{l}111 \ddagger / 218 \\
(51.0 \%) \S\end{array}$ & $\begin{array}{l}\text { OR } 2.4 \\
(1.6 \text { to } 3.6)\end{array}$ & - \\
\hline $\begin{array}{l}\text { Kiljander and } \\
\text { Laitinen, 2004 }\end{array}$ & Finland & $\begin{array}{l}\text { Cross- } \\
\text { sectional }\end{array}$ & $\begin{array}{l}\text { Random sample of } \\
\text { consecutive patients }\end{array}$ & Secondary care & Heartburn weekly & $\begin{array}{l}\text { Self-administered } \\
\text { questionnaire }\end{array}$ & $47 / 90(52.2 \%)$ & - & - & - \\
\hline $\begin{array}{l}\text { Ruigomez et al } \\
2005^{20}\end{array}$ & UK & $\begin{array}{l}\text { Cohort study } \\
\text { with nested } \\
\text { case-control } \\
\text { analysis }\end{array}$ & $\begin{array}{l}\text { Random sample } \\
\text { from GPRD }\end{array}$ & $\begin{array}{l}\text { Population- } \\
\text { based } \\
\text { administrative } \\
\text { database }\end{array}$ & $\begin{array}{l}\text { GORD diagnosed by } \\
\text { physician }\end{array}$ & Database review & $\begin{array}{l}\text { Incidence } 8 \text { per } \\
1000 \text { person-years } \\
(7.0-9.1) \\
(219 / 9712)\end{array}$ & $\begin{array}{l}\text { Incidence } 4.4 \\
\text { per } 1000 \\
\text { person-years } \\
(3.9-5.0) \mid 1 \\
(241 / 19334)\end{array}$ & - & $\begin{array}{l}\text { RR } 1.5 \\
(1.2 \text { to } 1.8) \#\end{array}$ \\
\hline $\begin{array}{l}\text { Shimizu et al } \\
2006^{36}\end{array}$ & Japan & $\begin{array}{l}\text { Cross- } \\
\text { sectional }\end{array}$ & Not given & $\begin{array}{l}\text { Secondary care, } \\
\text { asthma clinic }\end{array}$ & $\begin{array}{l}\text { QUEST score of at } \\
\text { least } 4^{\star \star}\end{array}$ & Questionnaire & $54 / 78(69.2 \%)$ & $\begin{array}{l}27 / 150 \\
(18.0 \%)+\dagger\end{array}$ & $\begin{array}{l}\text { OR } 10.3 \\
(5.4 \text { to } 19.4) \ddagger\end{array}$ & - \\
\hline
\end{tabular}

$\mathrm{Cl}$, Confidence interval; GPRD, General Practice Research Database; OR, odds ratio; QUEST, questionnaire for the diagnosis of reflux disease; RR, relative risk.

*Exact values provided by the author.

tControls were patients attending a family practice.

$\ddagger$ Calculated based on values given in publication.

$\S$ Controls were general medical clinic outpatients without pulmonary disease.

I Controls were age and sex-matched primary care patients without a diagnosis of asthma or gastro-oesophageal reflux disease (GORD) at baseline.

\#Adjusted for age, sex, smoking, previous morbidity and healthcare utilisation.

${ }^{*}$ QUEST score derived from seven questions about regurgitation and stomach and chest discomfort.

t†Controls were outpatients or patients admitted to the hospital because of diseases other than GORD or asthma.

included in the analysis (table 3), ${ }^{23-262830343549}$ all of which were cross-sectional and had a secondary care setting. The pooled sample-size weighted average prevalence of abnormal oesophageal acid exposure in asthma patients was $50.9 \%$. Only one study included a control group, but that study did not report the prevalence of abnormal acid exposure among the controls. ${ }^{30}$ Without any measure of the prevalence of abnormal acid exposure among controls, such as patients seen in a clinic other than an asthma clinic, it is not clear from the studies whether the rate of abnormal oesophageal acid exposure is higher than expected among patients with asthma or not. In total, 23 studies were excluded (table 4). $.^{37} 39414350-68$ All but one $^{28}$ of the nine included studies reported medication use, and bronchodilators were widely used.

The US study by Sontag and co-workers ${ }^{30}$ found the highest prevalence of abnormal pH over 24 hours, at $81.8 \%$, despite excluding patients who had a referral for GORD. That study considered more criteria in their analysis than other studies, examining the frequency of reflux episodes, acid contact times, and oesophageal acid clearance times measured using three different methods. Controls had significantly fewer reflux episodes $(p=0.0001)$, shorter total acid contact time $(\mathrm{p}<0.0001)$ and shorter oesophageal clearance times $(p=0.0001)$ than patients with asthma. When reported, there were no significant differences in medication use between patients with asthma who had normal and abnormal oesophageal pH. ${ }^{26} 303449$

Five studies also reported, as sub-analyses, the prevalence of abnormal oesophageal $\mathrm{pH}$ particularly in asthma patients without the typical symptoms of GORD of heartburn and/or acid regurgitation, giving an overall prevalence of $10-$ $50 \% .^{23242635}{ }^{49}$ In one study, ${ }^{23}$ significant predictors of abnormal

Table 2 Excluded studies reporting the prevalence of reflux symptoms among individuals with asthma, and reasons for exclusion

\begin{tabular}{|c|c|c|c|c|c|c|c|}
\hline Reference & $\begin{array}{l}\text { Sample size } \\
<50\end{array}$ & $\begin{array}{l}\text { Population } \\
\text { source not } \\
\text { reported }\end{array}$ & $\begin{array}{l}\text { Patients referred } \\
\text { for suspected } \\
\text { GORD }\end{array}$ & $\begin{array}{l}\text { Reflux symptoms } \\
\text { and/or frequency } \\
\text { not defined }\end{array}$ & $\begin{array}{l}\text { Respiratory symptoms } \\
\text { or diagnosis not } \\
\text { specific for asthma }\end{array}$ & $\begin{array}{l}\text { ATS criteria for asthma } \\
\text { diagnosis not satisfied } \\
\text { in secondary care setting }\end{array}$ & $\begin{array}{l}\text { Prevalence of reflux symptoms } \\
\text { in patients with asthma (\%) }\end{array}$ \\
\hline Perrin-Fayolle et al $1980^{37}$ & & & & $\checkmark$ & & & $126 / 150(84.0)$ \\
\hline Luo $1989^{38}$ & & & & & & $\checkmark$ & $34 / 55(61.8)$ \\
\hline Harding et al $1999^{39}$ & & & $\checkmark$ & & & & $164 / 199(82.4)$ \\
\hline Nakase et al $1999^{40}$ & & & & $\checkmark$ & & & $43 / 72(59.7)$ \\
\hline Harding et al $2000^{41}$ & & & & & & $\checkmark$ & $140 / 220(63.6)$ \\
\hline Mogica Martinez et al $2001^{42}$ & & & $\checkmark$ & $\checkmark$ & & $\checkmark$ & $71 / 100(71.0)$ \\
\hline Heaney et al $2003^{43}$ & & & & $\checkmark$ & & & $29 / 73(39.7)$ \\
\hline Al-Asoom et al $2003^{23}$ & & & & $\checkmark$ & & & $28 / 50(56.0)$ \\
\hline Liou et al $2003^{44}$ & & & & $\checkmark$ & & & $40 / 149(26.8)$ \\
\hline $\begin{array}{l}\text { Bochenska-Marciniak and Gorski, } \\
2004^{45}\end{array}$ & & & & $\checkmark$ & & & $131 / 208(63.0)$ \\
\hline Carlo et al $2005^{46}$ & $\checkmark$ & & & & & $\checkmark$ & $16 / 34(47.1)$ \\
\hline Gopal et al $2005^{47}$ & & & & & $\checkmark$ & $\checkmark$ & $52 / 70(74.3)$ \\
\hline Leggett et al $2005^{24}$ & & & & $\checkmark$ & & & $39 / 52(75.0)$ \\
\hline Chunlertrith ef al $2005^{48}$ & & & & $\checkmark$ & & & $86 / 151(57.0)$ \\
\hline
\end{tabular}

ATS, American Thoracic Society; GORD, gastro-oesophageal reflux disease. 


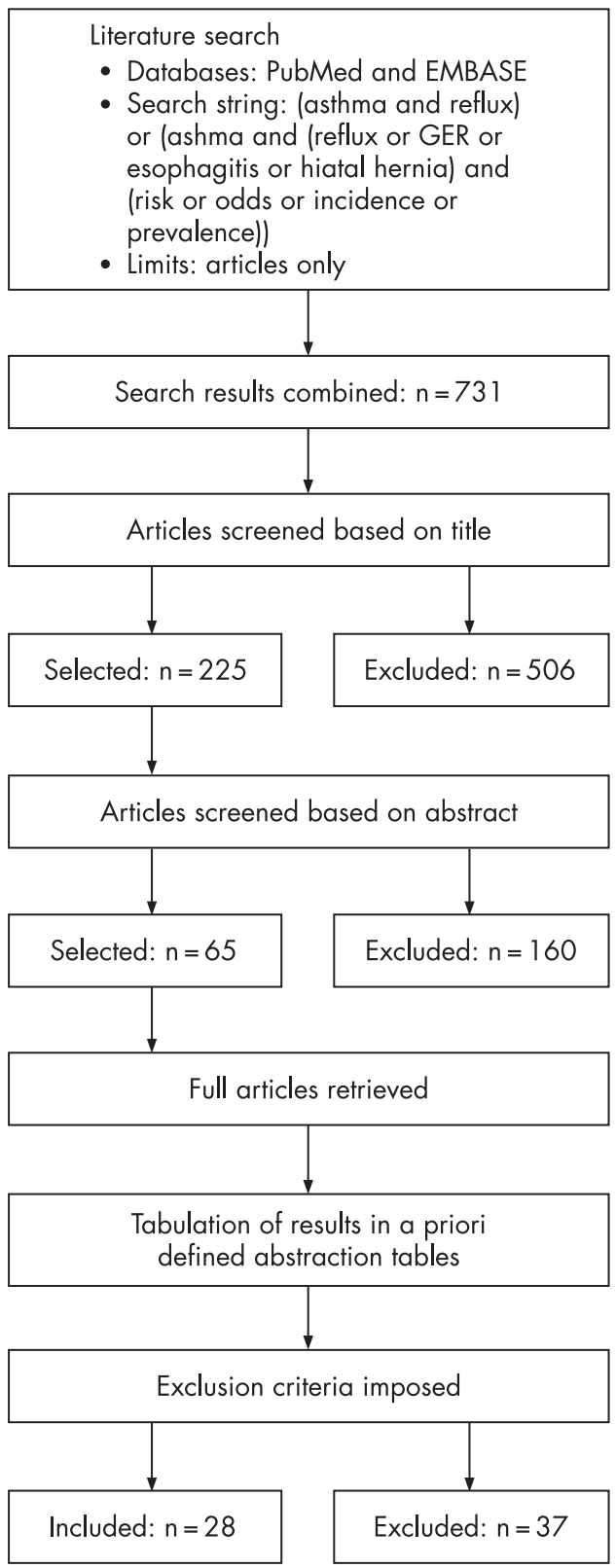

Figure 1 Literature search strategy.

GER, gastrooesophageal reflux.

$\mathrm{pH}$ were nocturnal asthma symptoms (OR 7.7; 95\% CI 1.8-32.7) and hoarseness (OR 6.6; 95\% CI 1.8-24.1). The frequency of symptoms was not, however, described by the authors. Another study specifically reported the frequency of night-time asthma symptoms, but found no significant difference between patients with normal and abnormal oesophageal $\mathrm{pH}^{49}$

\section{Studies reporting the results of endoscopy in patients with asthma}

We identified 18 studies in which endoscopy was performed in patients with asthma. Six studies satisfied our inclusion criteria (table 5), ${ }^{28} 3132364069$ and 12 studies were excluded from the analysis (table 6). $.^{37} 384661-63666870-72$ All of the included studies were cross-sectional and based in secondary care. The prevalence of erosive oesophagitis ranged from $27.8 \%$ to $47.4 \%$, giving a pooled sample-size weighted average prevalence of $37.3 \%$. The reported prevalence of hiatal hernia among patients with asthma ranged from $37.1 \%$ to $61.7 \%$, giving a pooled sample-size weighted average prevalence of $51.2 \%$. Only two

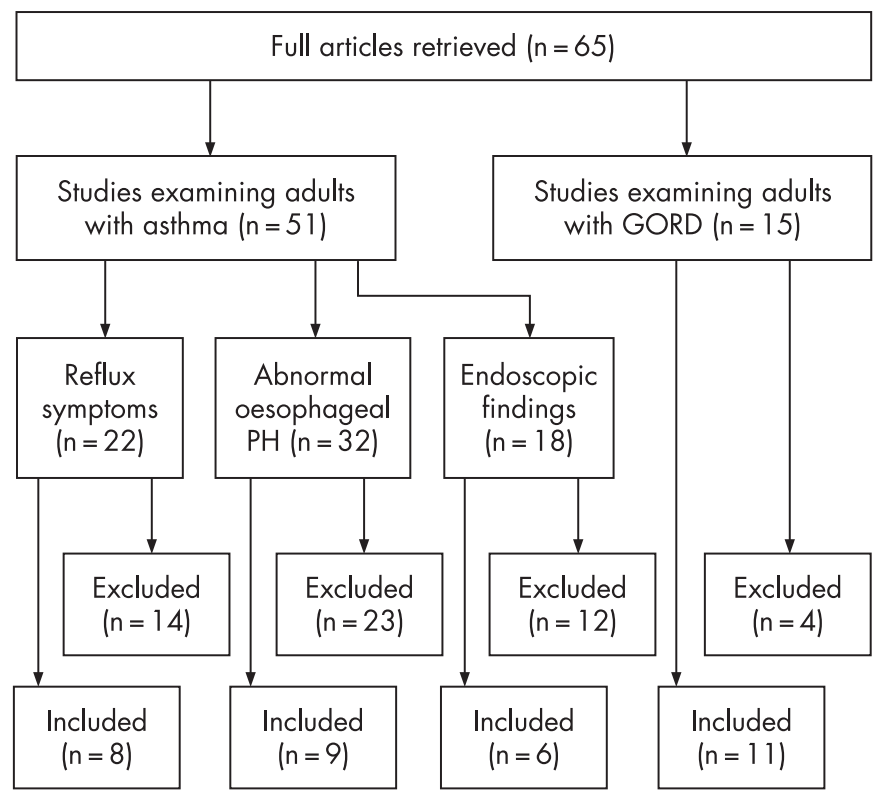

Figure 2 Organisation of articles retrieved from literature searches. GORD, gastro-oesophageal reflux disease.

studies included a control group, and in both studies there was a significant positive association between asthma and erosive oesophagitis or hiatal hernia (table 5)..$^{28} 36$

The level of bronchodilator use was not given in three of the studies. ${ }^{28} 3640$ In the study by Sontag et al., ${ }^{32} 75 \%$ of patients used bronchodilators, and there was no significant difference between the prevalence of oesophagitis in those taking and not taking this medication. Bronchodilator use was similarly high $(72 \%)$ in the study performed by Avidan and colleagues. ${ }^{31}$ In another study, ${ }^{69}$ although the level of bronchodilator use was not reported directly, the authors did state that drug consumption did not differ between those patients with oesophageal dysfunction (including hiatal hernia, oesophagitis, dysmotility or low lower oesophageal sphincter pressure) and those without. That study also found that frequent wheezing and cough was significantly more common among patients with oesophageal dysfunction than those without, but there were no significant differences in spirometric measurements between the two groups.

\section{Asthma in individuals with GORD}

We identified a total of 15 studies that evaluated the presence of asthma in adults with GORD. Eleven studies met our inclusion criteria (table 7$)^{20273373-80}$ and four studies were excluded (table 8). ${ }^{81-84}$ Of the included studies, nine were crosssectional and two were cohort studies. Seven studies were general population surveys, three took their data from large administrative databases and one was based in secondary care. Nine studies reported the prevalence of asthma in individuals with GORD, giving an average prevalence of $4.6 \%$. The average prevalence in controls was $3.9 \%$, reported in seven of the studies. When only those studies that reported the prevalence of at least weekly heartburn and/or acid regurgitation were included $(n=4)$, the average prevalence increased to $12.3 \%$, largely because of the exclusion of a very large database study ( $\mathrm{n}=101366$ ), which reported the lowest prevalence of asthma in GORD (4.3\%). ${ }^{33}$ Overall, seven cross-sectional studies included a control group (table 7). Pooling the unadjusted odds ratios using a random effects model gave an overall odds ratio of 2.27 (95\% CI 1.814-2.834; fig 5). The calculated I ${ }^{2}$ was $85 \%$, however, indicating considerable heterogeneity. Six of 
Table 3 Included studies in which 24 hour oesophageal pH monitoring in patients with asthma was performed

\begin{tabular}{|c|c|c|c|c|c|}
\hline Reference & Country & Study design & Patient recruitment & Population source & $\begin{array}{l}\text { Prevalence of abnormal oesophageal acid } \\
\text { exposure in patients with asthma (\%) }\end{array}$ \\
\hline Sontag et al $1990^{30}$ & USA & Cross-sectional & Consecutive & $\begin{array}{l}\text { Secondary care, } \\
\text { asthma clinic }\end{array}$ & $85^{*} / 104(81.8)$ \\
\hline Suzuki et al $1997^{25}$ & Japan & Cross-sectional & Not reported & Secondary care & $42 / 58(72.4)$ \\
\hline Vincent et al $1997^{26}$ & France & Cross-sectional & Consecutive & $\begin{array}{l}\text { Secondary care, } \\
\text { asthma clinic }\end{array}$ & $30 / 94(31.9)$ \\
\hline Kiljander et al $1999^{49}$ & Finland & Cross-sectional & Not reported & $\begin{array}{l}\text { Secondary care, } \\
\text { asthma clinic }\end{array}$ & $57 / 107$ (53.3) \\
\hline $\begin{array}{l}\text { Carmona-Sanchez et al } \\
1999^{28}\end{array}$ & Mexico & Cross-sectional & Consecutive & $\begin{array}{l}\text { Secondary care, } \\
\text { asthma clinic }\end{array}$ & $45 / 60(75.0)$ \\
\hline Compte et al $2000^{34}$ & Spain & Cross-sectional & Consecutive & $\begin{array}{l}\text { Secondary care, } \\
\text { asthma clinic }\end{array}$ & $12 / 81(14.8)$ \\
\hline Al-Asoom et al $2003^{23}$ & Saudi Arabia & Cross-sectional & Consecutive & $\begin{array}{l}\text { Secondary care, } \\
\text { asthma clinic }\end{array}$ & $22 / 50(44.0)$ \\
\hline $\begin{array}{l}\text { Kiljander and Laitinen } \\
2004^{35}\end{array}$ & Finland & Cross-sectional & $\begin{array}{l}\text { Random sample of consecutive } \\
\text { patients }\end{array}$ & Secondary care & $32 / 90(35.6)$ \\
\hline Leggett et al $2005^{24}$ & UK & Cross-sectional & Not reported & $\begin{array}{l}\text { Secondary care, } \\
\text { asthma clinic }\end{array}$ & $29 / 52(55.8)$ \\
\hline
\end{tabular}

those studies with controls were population based and were thus considered to be of high generalisability. When only those studies were included in the analysis, the pooled odds ratio was 2.68 (95\% CI $1.82-3.96)$ and the $\mathrm{I}^{2}$ test gave a value of $81 \%$. Only one study reported medication use, finding no association between the current use of gastrointestinal drugs and the occurrence of asthma. ${ }^{20}$

There were two cohort analyses that reported incidence estimates for asthma in individuals with GORD, or a complication associated with GORD. One of these, which was a followup study from the third US National Health and Nutrition Examination Survey (NHANES III), found that the incidence rate of hospitalisation as a result of asthma in patients who had had previous hospitalisation for hiatal hernia or oesophagitis was 2.6 cases per 1000 person-years, whereas in controls without hiatal hernia or oesophagitis it was 1.0 cases per 1000 person-years. $^{74}$ The other study used a UK primary care administrative database, and found an incidence rate of a new diagnosis of asthma among patients with an existing diagnosis of GORD of 6.0 (95\% CI 4.9-7.3) per 1000 personyears. ${ }^{20}$ In patients without a previous diagnosis of GORD, the incidence rate of asthma was significantly lower at 3.8 cases (95\% CI 3.1-4.6) per 1000 person-years.

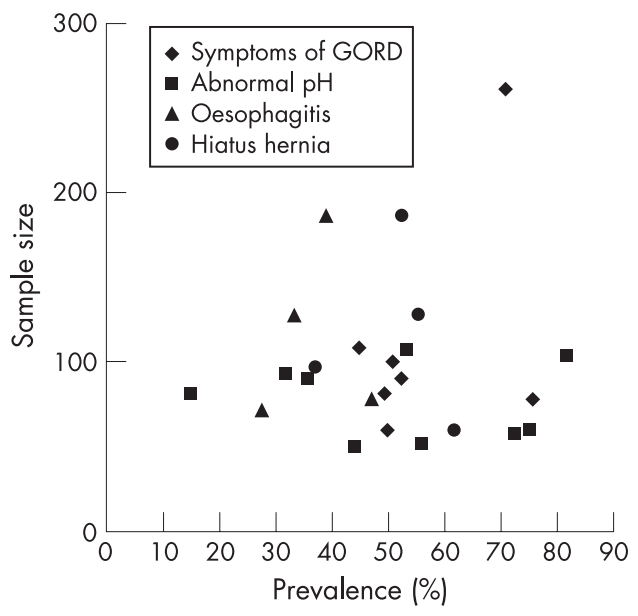

Figure 3 Funnel plot showing the prevalence of gastro-oesophageal reflux disease in individuals with asthma against sample size. GORD, gastro-oesophageal reflux disease.

\section{Severity-response relationship between GORD and asthma}

Only three of the studies evaluating the presence of symptoms of GORD in individuals with asthma considered whether the severity of asthma had an impact on the presence, severity or frequency of GORD symptoms. One study from Italy found that a greater proportion of patients with severe asthma experienced at least twice weekly heartburn and/or acid regurgitation than those with mild or moderate symptoms $(\mathrm{p}<0.03) .{ }^{21}$ Reflux symptoms were present in $30 \%$ of patients with mild asthma, $46 \%$ of those with moderate asthma and $70 \%$ of those with severe asthma. ${ }^{21}$ In a cross-sectional study from Spain, ${ }^{34}$ a composite score for GORD was calculated based on the percentage of time that $\mathrm{pH}$ was less than four in upright and supine positions and in total, the number of reflux episodes in total, the number of reflux episodes longer than five minutes and the duration of the longest reflux episode. The value of this composite score was similar in patients with mild asthma (median 8.8; range 8.0-22.1), moderate asthma (median 9.5; range 7.9144.5) and severe asthma (median 10.5; range 8.0-66.6). ${ }^{34}$

Vincent and colleagues ${ }^{26}$ found that in patients with GORD, there was a very strong association between the provocative dose of methacholine causing a $20 \%$ fall in $\mathrm{FEV}_{1}$ and the number of oesophageal reflux episodes $(\mathrm{p}<0.001)$. There were, however, no other correlations between lung function $\left(\mathrm{FEV}_{1}\right.$ or mean expiratory flow) and GORD criteria (percentage of 24hour period with oesophageal $\mathrm{pH}<4$, number of reflux episodes or lower oesophageal sphincter pressure).

Only two endoscopy studies examined the association between the severity of asthma and the severity of endoscopic findings. Overall, they indicated that more severe asthma is associated with an increased risk of GORD. In one study from Japan, $^{40}$ patients with intermittent, mildly persistent or moderately persistent asthma had a lower mean endoscopic grade of oesophagitis than patients with severe asthma $(\mathrm{p}<0.05)$. In the other study, ${ }^{36}$ also from Japan, patients with mild asthma were most frequently classified as having no apparent mucosal changes, those with moderate asthma most frequently had minimal changes, and those with severe asthma most frequently had oesophagitis of Los Angeles grade A (mucosal break $\leqslant 5 \mathrm{~mm}$ ).

In the studies that examined the presence of asthma in individuals with GORD, the severity of GORD defined by the frequency of reflux symptoms was associated with a higher prevalence of asthma in three studies (fig 6). ${ }^{73}{ }^{78} 80$ Another study found that there was a higher prevalence of asthma 
Table 4 Excluded studies in which oesophageal pH monitoring was performed in patients with asthma, and the reasons for exclusion

\begin{tabular}{|c|c|c|c|c|c|c|}
\hline Reference & $\begin{array}{l}\text { Sample size } \\
<50\end{array}$ & $\begin{array}{l}\text { Population source } \\
\text { not reported }\end{array}$ & $\begin{array}{l}\text { Patients referred for } \\
\text { suspected GORD }\end{array}$ & $\begin{array}{l}\text { pH Monitoring for } \\
<24 \text { hours }\end{array}$ & $\begin{array}{l}\text { ATS criteria for asthma } \\
\text { diagnosis not satisfied }\end{array}$ & $\begin{array}{l}\text { Prevalence of abnormal } \\
\text { oesophageal acid exposure in } \\
\text { patients with asthma (\%) }\end{array}$ \\
\hline $\begin{array}{l}\text { Perrin-Fayolle et al } \\
1980^{37}\end{array}$ & & & & & $\checkmark$ & $138 / 150(92.0)$ \\
\hline Perpina et al $1983^{50}$ & $\checkmark$ & $\checkmark$ & & $\checkmark$ & & $9 / 26(34.6)$ \\
\hline Ducolone et al $1987^{51}$ & 21 & 1 & & 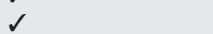 & & $11 / 21(52.4)$ \\
\hline $\begin{array}{l}\text { Ekstrom and Tibbling } \\
1988^{52}\end{array}$ & 4 & & $\checkmark$ & & & $18 / 37(48.6)$ \\
\hline Nagel et al $1988^{53}$ & $d$ & & & & $\checkmark$ & $15 / 44(34.1)$ \\
\hline Guidicelli et al $1990^{54}$ & & & & & 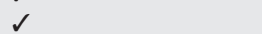 & $76 / 121(62.8)$ \\
\hline $\begin{array}{l}\text { DeMeester et al } \\
1990^{55}\end{array}$ & & & & & $\checkmark$ & $54 / 77(70.1)$ \\
\hline Larrain et al $1991^{56}$ & & & & $\checkmark$ & $\checkmark$ & $94 / 142(66.2)$ \\
\hline Herve et al $1993^{57}$ & & 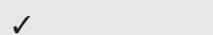 & & & & $41 / 53(77.4)$ \\
\hline Gastal et al $1994^{58}$ & $d$ & & $\checkmark$ & & & $12 / 25(48.0)$ \\
\hline Schnatz ef al $1996^{59}$ & & & $\checkmark$ & & $\checkmark$ & $42 / 54(77.8)$ \\
\hline Suh et al $1997^{60}$ & $\checkmark$ & & & & 2 & $11 / 42(26.2)$ \\
\hline Campo et al $1997^{61}$ & 1 & & 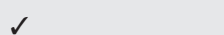 & & & $14 / 17(82.4)$ \\
\hline Dal Negro et al & $\checkmark$ & & & & & $30 / 37(81.1)$ \\
\hline Harding et al $1999^{39}$ & & & $\checkmark$ & & & $128 / 199(64.3)$ \\
\hline $\begin{array}{l}\text { Garcia-Compean et al } \\
2000^{63}\end{array}$ & & & & & $\checkmark$ & $34 / 57(59.6)$ \\
\hline Harding et al $2000^{41}$. & $\checkmark$ & & $\checkmark$ & & & $16 / 26(61.5)$ \\
\hline Heaney et al $2003^{43}$ & & & & & $a$ & $31 / 54(57.4)$ \\
\hline Oldigs $2004^{64}$ & & & a & & 3 & $39 / 63(61.9)$ \\
\hline Paleev et al $2005^{65}$ & $\checkmark$ & & & & 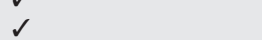 & $17 / 37(45.9)$ \\
\hline Hsu et al $2005^{66}$ & & 2 & $d$ & & & $29 / 56(51.8)$ \\
\hline Sami et al $2006^{67}$ & & & 1 & & 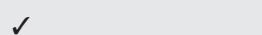 & $25 / 50(50.0)$ \\
\hline Wong et al $2006^{68}$ & $\checkmark$ & & & & & $17 / 30(56.7)$ \\
\hline
\end{tabular}

ATS, American Thoracic Society; GORD, gastro-oesophageal reflux disease.

among patients who had GORD and erosive oesophagitis (169/ $2114,5.2 \%$ ) than those who had GORD without erosive oesophagitis $(127 / 2065,4.3 \%))^{76}$

\section{Temporal sequence relationship between GORD and asthma}

The temporal relationship between GORD and asthma was investigated in two studies. ${ }^{20}{ }^{74}$ One of those studies, ${ }^{20}$ which used the UK General Practice Research Database, found a clear association between the presence of a new diagnosis of asthma and the subsequent development of GORD in a multivariate analysis adjusted for age, sex, smoking, previous morbidity and healthcare utilisation (RR 1.5; 95\% CI 1.2-1.8). That study also assessed the likelihood of GORD preceding asthma, showing a non-significantly increased risk of a new diagnosis of asthma among patients with GORD compared with those in the control cohort without GORD (RR 1.2; 95\% CI 0.9-1.6). ${ }^{20}$ The longitudinal US study that used the NHANES III data ${ }^{74}$ showed an increased likelihood of hospitalisation as a result of asthma in individuals who had previously been hospitalised with oesophagitis or hiatal hernia (RR 2.1; 95\% CI 1.1-4.2).

\section{DISCUSSION}

The findings of our systematic review support a significant association between GORD and asthma. The pooled prevalence values indicate that the prevalence of symptoms of GORD among individuals with asthma is substantially higher (1.6fold) than in controls. Similarly, although to a lesser degree, the

Table 5 Included studies reporting endoscopic oesophageal findings in patients with asthma

\begin{tabular}{|c|c|c|c|c|c|c|c|c|c|c|}
\hline Reference & Country & Study design & Patient recruitment & Sampling frame & $\begin{array}{l}\text { Prevalence of hiatal } \\
\text { hernia in patients } \\
\text { with asthma }\end{array}$ & $\begin{array}{l}\text { Prevalence of } \\
\text { erosive oesophagitis } \\
\text { in patients with } \\
\text { asthma }\end{array}$ & $\begin{array}{l}\text { Prevalence of } \\
\text { Barrett's } \\
\text { oesophagus in } \\
\text { patients with } \\
\text { asthma }\end{array}$ & $\begin{array}{l}\text { Prevalence of } \\
\text { erosive } \\
\text { oesophagitis in } \\
\text { controls }\end{array}$ & $\begin{array}{l}\text { Prevalence of } \\
\text { hiatal hernia } \\
\text { in controls }\end{array}$ & $\begin{array}{l}\text { Unadjusted odds } \\
\text { ratio/relative risk } \\
(95 \% \mathrm{CI})\end{array}$ \\
\hline $\begin{array}{l}\text { Kiellen et al } \\
1981^{69}\end{array}$ & Sweden & $\begin{array}{l}\text { Cross- } \\
\text { sectional }\end{array}$ & Consecutive & $\begin{array}{l}\text { Secondary care, } \\
\text { asthma clinic }\end{array}$ & $36 / 97(37.1 \%)$ & - & - & - & - & - \\
\hline $\begin{array}{l}\text { Sontag et al } \\
1992^{32}\end{array}$ & USA & $\begin{array}{l}\text { Cross- } \\
\text { sectional }\end{array}$ & Consecutive & $\begin{array}{l}\text { Secondary care, } \\
\text { asthma clinic }\end{array}$ & $97 / 186(52.2 \%)$ & $73 / 186(39.2 \%)$ & $24 / 186(12.9 \%)$ & - & - & - \\
\hline $\begin{array}{l}\text { Carmona-Sanchez } \\
\text { ef al } 1999^{28}\end{array}$ & Mexico & $\begin{array}{l}\text { Cross- } \\
\text { sectional }\end{array}$ & Consecutive & $\begin{array}{l}\text { Secondary care, } \\
\text { asthma clinic }\end{array}$ & $37 / 60(61.7 \%)$ & - & - & - & $61 / 180(33.9 \%)^{*}$ & ${ }^{*} \operatorname{RR} 3.13(1.64$ to 6.01$)$ \\
\hline $\begin{array}{l}\text { Avidan et al } \\
2001^{31}\end{array}$ & USA & $\begin{array}{l}\text { Cross- } \\
\text { sectional }\end{array}$ & Consecutive & $\begin{array}{l}\text { Secondary care, } \\
\text { asthma clinic }\end{array}$ & $71 / 128(55.5 \%)$ & $43 / 128(33.6 \%)$ & - & - & - & - \\
\hline $\begin{array}{l}\text { Nakase et al } \\
1999^{40}\end{array}$ & Japan & $\begin{array}{l}\text { Cross- } \\
\text { sectional }\end{array}$ & Consecutive & Secondary care & - & $20+/ 72(27.8 \%)$ & - & - & - & - \\
\hline $\begin{array}{l}\text { Shimizu et al } \\
2006^{36}\end{array}$ & Japan & $\begin{array}{l}\text { Cross- } \\
\text { sectional }\end{array}$ & Consecutive & $\begin{array}{l}\text { Secondary care, } \\
\text { asthma clinic }\end{array}$ & - & $37 / 78(47.4 \%)$ & - & $6 / 150(4.0 \%) \ddagger$ & - & OR 21.7 (8.5 to 54.9$) \dagger$ \\
\hline
\end{tabular}

$\mathrm{Cl}$, Confidence interval; OR, odds ratio; $\mathrm{RR}$, relative risk

*Controls were patients with dyspeptic symptoms, including heartburn and/or acid regurgitation, but without oesophagitis or previous gastric surgery

†Calculated based on values given in publication.

$\ddagger$ Controls were outpatients who had visited the hospital for a routine health examination. 


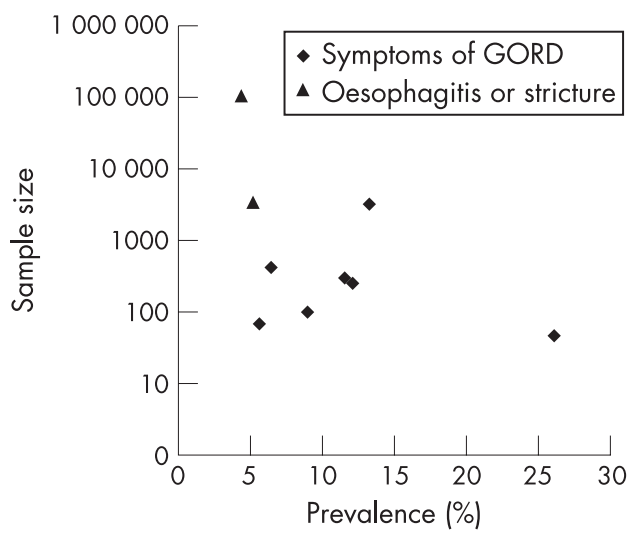

Figure 4 Funnel plot showing the prevalence of asthma in individuals with gastro-oesophageal reflux disease against sample size.

GORD, gastro-oesophageal reflux disease.

average prevalence of asthma in individuals with GORD is also higher than in controls (1.2-fold). The average prevalence of reflux symptoms in adults with asthma was 59\%, and the prevalence of erosive oesophagitis was 37\%. The average prevalence of GORD diagnosed by $\mathrm{pH}$ monitoring was $51 \%$. These values in individuals with asthma are substantially higher than those reported in the general population (10-20\% for GORD symptoms, 7-16\% for erosive oesophagitis ${ }^{11} 141585$ ). None of the studies reporting the prevalence of GORD in asthma were population based, however, and some of this difference may be because the subjects came from selected primary and secondary care populations.

Although there appears to be a strong association between GORD and asthma, most of the studies included in our analysis were cross-sectional or case-control in design, and therefore could not give a clear indication of the temporal sequence of these conditions, an important criterion for causal associations. The temporal sequence between GORD and asthma was explored in only two studies. The single study that assessed whether primary care patients with asthma were at an increased risk of subsequently developing GORD found a significantly increased incidence of GORD among those patients compared with controls. That and another study reported the likelihood of GORD preceding asthma, with inconsistent findings. Similarly, the severity-response relationship, another criterion for a causal association, was reported in a minority of studies. Results were again inconsistent, but tended towards a positive correlation when the increasing severity of GORD (based on either increasing symptom frequency or the increasing severity of oesophagitis) was associated with an increase in the prevalence of asthma. In several studies, increasingly severe asthma was associated with an increased prevalence of symptoms of GORD or severity of GORD. As a result, the available evidence does not yet clearly indicate whether GORD precedes asthma, or asthma triggers GORD. The recently published Montreal definition of GORD concludes that GORD can be an "aggravating cofactor" in asthma. ${ }^{1}$

In addition to statistical association and temporal and severity-response relationships, the controlled introduction or

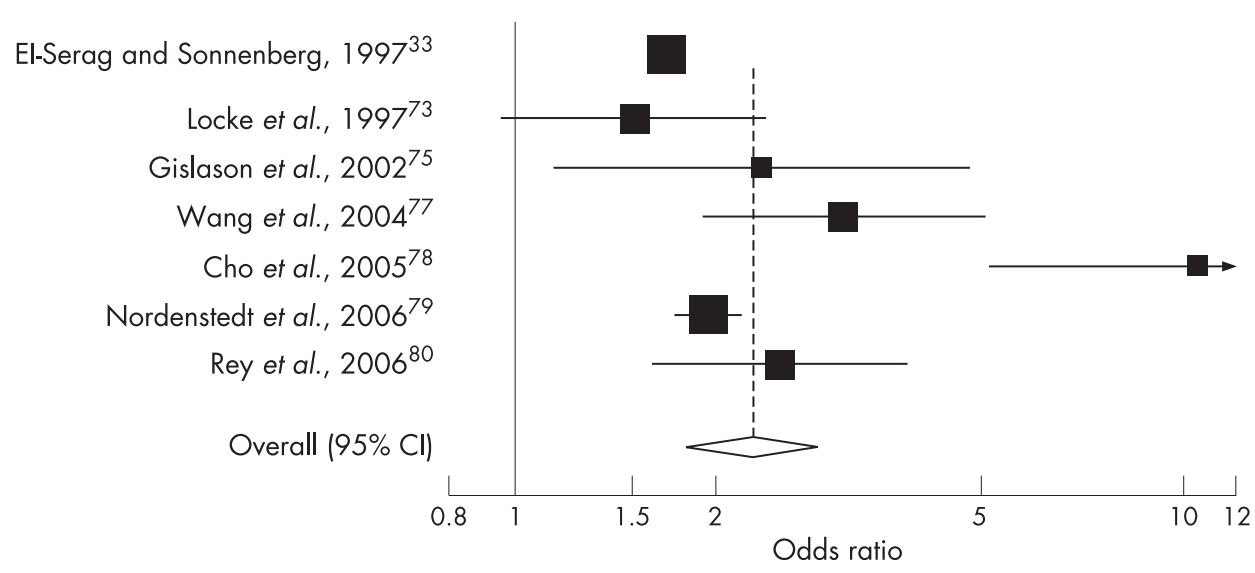

Figure 5 A forest plot of odds ratios obtained from seven cross-sectional studies that examined the prevalence of asthma among patients with GORD. The point estimate and $95 \% \mathrm{Cl}$ for the pooled odds ratio (represented by the diamond) is 2.26 (1.813-2.834).

Table 6 Excluded studies reporting endoscopic oesophageal findings in patients with asthma, and reasons for exclusion

\begin{tabular}{|c|c|c|c|c|c|c|c|}
\hline Reference & $\begin{array}{l}\text { Sample size } \\
<50\end{array}$ & $\begin{array}{l}\text { Population } \\
\text { source not } \\
\text { reported }\end{array}$ & $\begin{array}{l}\text { Patients referred } \\
\text { for suspected } \\
\text { GORD }\end{array}$ & $\begin{array}{l}\text { ATS criteria not } \\
\text { satisfied }\end{array}$ & $\begin{array}{l}\text { Prevalence of } \\
\text { oesophagitis in patients } \\
\text { with asthma (\%) }\end{array}$ & $\begin{array}{l}\text { Prevalence of hiatal } \\
\text { hernia in patients with } \\
\text { asthma (\%) }\end{array}$ & $\begin{array}{l}\text { Prevalence of Barrett's } \\
\text { oesophagus in patients } \\
\text { with asthma (\%) }\end{array}$ \\
\hline Mays $1976^{70}$ & $\checkmark$ & & & $\checkmark$ & $13 / 28(46.4)$ & $18 / 28(64.3)$ & \\
\hline Diez Gomez et al $1979^{71}$ & & & & $\checkmark$ & $23 / 82(28.0)$ & & \\
\hline Perrin-Fayolle et al $1980^{37}$ & & & & $\checkmark$ & & $32 / 150(21.3)$ & \\
\hline Luo $1989^{38}$ & & & & $\checkmark$ & $35 / 55(63.6)^{*}$ & & \\
\hline Campo et al $1997^{61}$ & $\checkmark$ & & $\checkmark$ & & $11 / 13(84.6)$ & & \\
\hline Dal Negro et al $1999^{62}$ & $\checkmark$ & & & & & $10 / 37(27.0)$ & \\
\hline Garcia-Compean et al $2000^{63}$ & & & & $\checkmark$ & $6 / 57(10.5)$ & $18 / 57(31.6)$ & $3 / 57(5.3)$ \\
\hline Mogica Martinez et al $2001^{42}$ & & & $\checkmark$ & $\checkmark$ & & $33 / 100(33.0)$ & \\
\hline Ben-Noun $2001^{72}$ & & & $\checkmark$ & $\checkmark$ & & $19+/ 141(13.50)$ & \\
\hline Carlo et al $2005^{46}$ & $\checkmark$ & & & & $7 / 27(3.7)$ & & \\
\hline Hsu et al $2005^{66}$ & & $\checkmark$ & $\checkmark$ & & & $6 / 56(10.7)$ & \\
\hline Wong et al $2006^{68}$ & $\checkmark$ & & & & $10 / 30(33.3)$ & & \\
\hline
\end{tabular}

ATS: American Thoracic Society; GORD: gastro-oesophageal reflux disease.

*Prevalence of oesophagitis, hiatal hernia or Barrett's oesophagus in patients with asthma. 


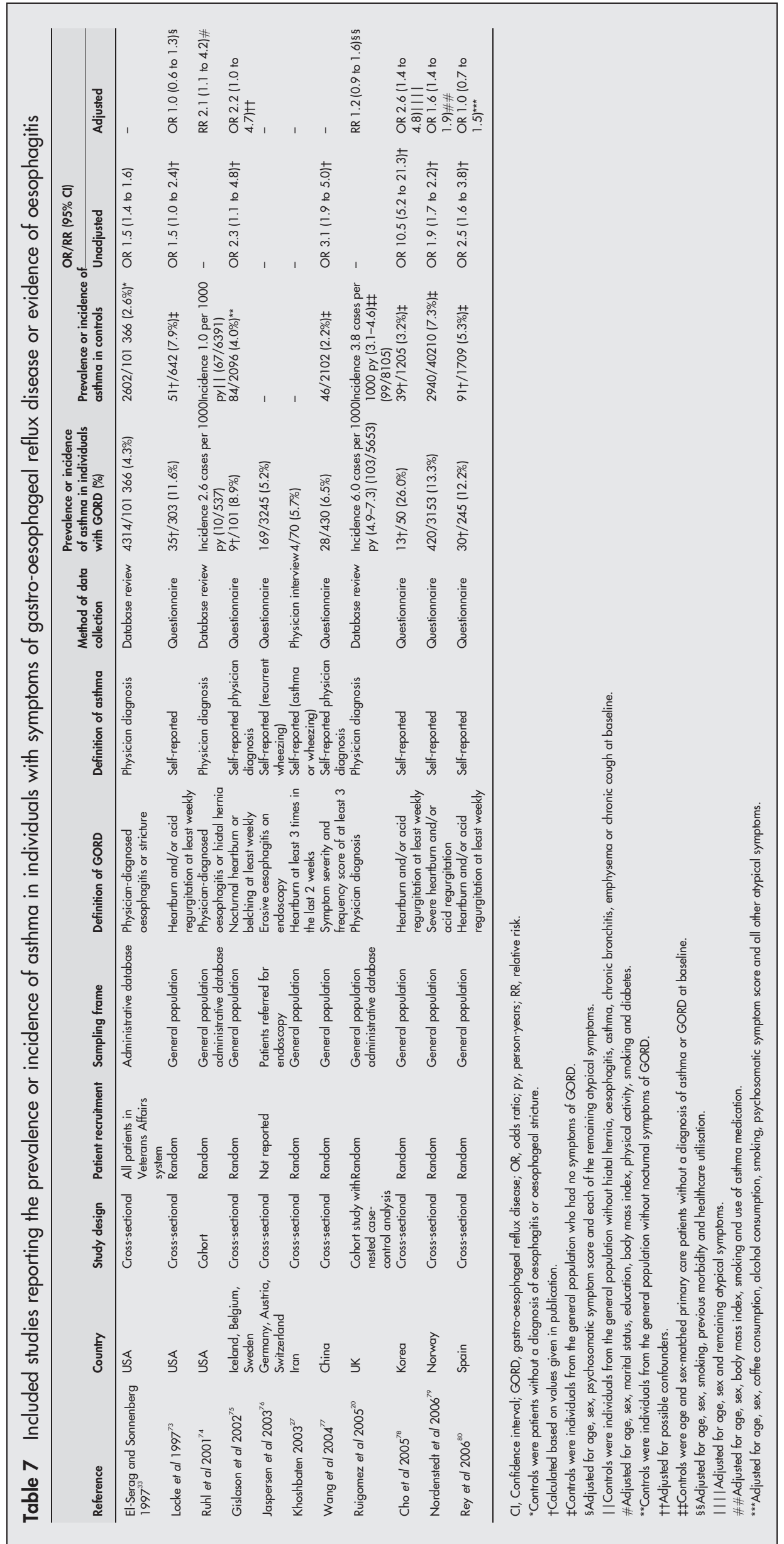

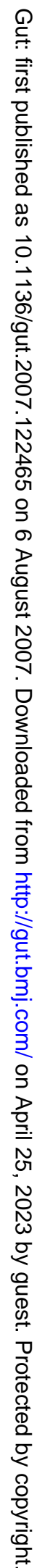




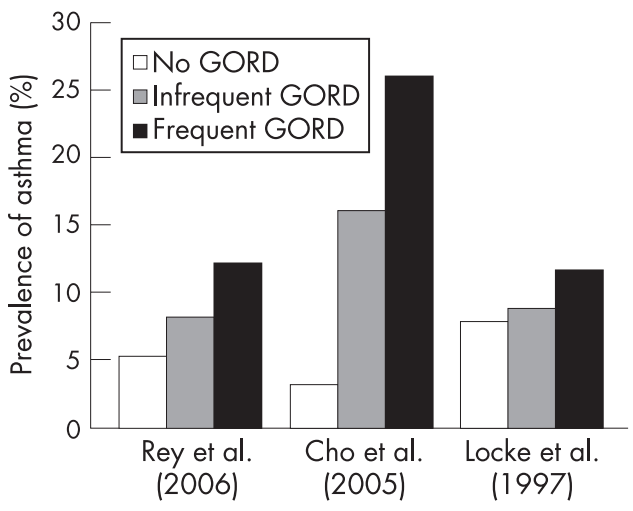

Figure 6 The severity-response relationship between symptoms of gastrooesophageal reflux disease and asthma.

GORD, Gastro-oesophageal reflux disease.

removal of stimuli related to one condition (such as GORD) and the corresponding response (such as the effect on asthma symptoms or pulmonary function) have been used to examine the potential for a causal relationship between the two conditions. This has been investigated using oesophageal acid perfusion testing, but no consistent effect has been found. ${ }^{86}$ GORD treatment in patients with asthma has also had mixed results. A recent systematic review showed minimal improvement of asthma symptoms with GORD therapy, but no improvement in objective pulmonary function indices. ${ }^{87}$ Antireflux therapy does, however, allow a reduction in asthma medication use. ${ }^{4}$ This difference in effect may be related to the fact that pharmacological treatments for GORD change the composition of refluxate without preventing reflux itself, whereas antireflux surgery reduces the number of reflux events. It may be that only some patients are sensitive to acid reflux, or that GORD may affect asthma symptoms but not the pulmonary function measures used in those studies. ${ }^{4}{ }^{9}$ For example, increased respiratory effort could be a result of the pain of heartburn causing increased minute ventilation rather than triggering bronchospasm. Even if asthma is GORD related, in some cases there may be resistance to GORD treatment through chronic or irreversible changes.

Our systematic review has both strengths and limitations. We present the most comprehensive systematic review of the epidemiological and clinical literature in this area. In particular, consistent definitions of GORD and asthma provide as true a representation of the prevalence of these diseases as possible. The results of our statistical funnel plot testing argue against the presence of publication bias. We have attempted to minimise selection bias by excluding studies in which investigated asthma patients were referred on the basis of a suspicion of underlying GORD. Most of the studies included in our review were, however, based in secondary and tertiary referral centres and thus have limited generalisability because they are subject to selection bias. In particular, the results from endoscopic and oesophageal pH monitoring studies may have limited generalisability because a large proportion of eligible patients will not give consent for these invasive and sometimes uncomfortable procedures, especially if the procedure is for the purpose of research only. Most studies had no internal controls and this aspect may have led to an overestimation of the association between GORD and asthma, as patients with difficult-to-control disease or suspicion of another causative factor may be overrepresented in these populations. Although we did not employ formal scoring of the studies in this review based on quality, we did perform a secondary analysis of studies with greater generalisability including only those that were population based and included internal controls. Six studies measuring the prevalence of asthma in individuals with GORD met these generalisability criteria, and the pooled odds ratios from those studies were indicative of a significant positive association between GORD symptoms and asthma.

Although there are a great many studies reporting the prevalence of GORD in individuals with asthma, and vice versa, we found very few population-based studies, and very few studies that considered the temporal sequence relationship between the two diseases. This type of epidemiological research would add to our understanding of the link between GORD and asthma. Prospective studies of individuals with GORD that include long-term follow-up and systematic testing for the incidence of asthma, and vice versa, would be the most valuable strategy. Further studies should also evaluate the severityresponse relationship between the two diseases. Ideally, studies should include internal controls and adequate numbers of patients to avoid type 2 errors. They should also document, using validated and reproducible measures, the severity of asthma, GORD and oesophagitis. Age is an important factor in relation to the onset of asthma. Most asthma diagnoses are made in childhood, whereas most 'difficult to control' asthma is thought to originate in adult life. ${ }^{88}$ It would be interesting to investigate whether age plays a role in GORD-related asthma.

In conclusion, this systematic review quantifies the prevalence of GORD in individuals with asthma, and asthma in GORD, and so contributes to our understanding of the association between these two diseases. It also highlights that, despite the enormous volume of literature that exists on the subject, there is a shortage of high-quality data. We have identified a clear paucity of data on the direction of the temporal sequence association. Addressing this should be a focus for future epidemiological research in this area.

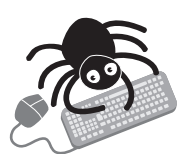

Competing interests: Declared (the declaration can be viewed on the Gut website at http://www.gutinl.com/ supplemental).

Table 8 Excluded studies reporting the prevalence or incidence of asthma in individuals with symptoms of gastro-oesophageal reflux disease, or evidence of oesophagitis, and reasons for exclusion

\begin{tabular}{|c|c|c|c|c|c|c|c|}
\hline Reference & $\begin{array}{l}\text { Sample size } \\
<50\end{array}$ & $\begin{array}{l}\text { Population } \\
\text { source not } \\
\text { reported }\end{array}$ & $\begin{array}{l}\text { Patients referred } \\
\text { for suspected } \\
\text { asthma }\end{array}$ & $\begin{array}{l}\text { Reflux symptoms not } \\
\text { defined, or GORD or } \\
\text { oesophagitis not } \\
\text { diagnosed by physician }\end{array}$ & $\begin{array}{l}\text { ATS criteria for asthma } \\
\text { diagnosis not satisfied } \\
\text { in secondary care } \\
\text { setting }\end{array}$ & $\begin{array}{l}\text { Respiratory } \\
\text { symptoms or } \\
\text { diagnosis not } \\
\text { specific for asthma }\end{array}$ & $\begin{array}{l}\text { Prevalence of asthma in } \\
\text { individuals with GORD or } \\
\text { oesophagitis (\%) }\end{array}$ \\
\hline Bagnato ef al $2000^{81}$ & $\checkmark$ & & & & & & $11 / 30(36.7)$ \\
\hline Riccioni et al $2004^{82}$ & $\checkmark$ & & & & & & $7 / 22(31.8)$ \\
\hline Roka et al $2005^{83}$ & & & & & $\checkmark$ & & $10 / 299(3.3)$ \\
\hline Li et al $2006^{84}$ & & & & $\checkmark$ & & & $4 / 200(2.0)$ \\
\hline
\end{tabular}

ATS, American Thoracic Society; GORD, gastro-oesophageal reflux disease. 


\section{Authors' affiliations}

B D Havemann, H B El-Serag, Sections of Gastroenterology and Health Services Research at the Houston Department of Veterans Affairs Medical Center, and Department of Medicine, Baylor College of Medicine, Houston, Texas, USA

C A Henderson, Research Evaluation Unit, Oxford PharmaGenesis Ltd, Oxford, UK

Funding: This study was funded by a research grant from AstraZeneca R\&D Mölndal, Sweden.

\section{REFERENCES}

1 Vakil N, Veldhuyzen van Zanten S, Kahrilas $P$, et al. The Montreal definition and classification of gastro-esophageal reflux disease (GERD) - a global evidencebased consensus. Am J Gastroenterol 2006;101:1900-20.

2 Shaheen N, Ransohoff DF. Gastroesophageal reflux, Barrett esophagus, and esophageal cancer: scientific review. JAMA 2002;287:1972-81.

3 Hungin AP, Raghunath A, Wiklund I. Beyond heartburn: a review of the spectrum of reflux-induced disease. Fam Pract 2005;22:591-603.

4 Field SK. Gastroesophageal reflux and asthma: are they related? J Asthma 1999;36:631-44.

5 Sontag SJ. Gastroesophageal reflux disease and asthma. J Clin Gastroenterol 2000;(Suppl 3):S9-30.

6 Castell DO, Schnatz PF. Gastroesophageal reflux disease and asthma. Reflux or reflex? Chest 1995;108:1186-7

7 Field SK. Asthma and gastroesophageal reflux: another piece in the puzzle? Chest 2002;121:1024-7.

8 Sloan S, Rademaker AW, Kahrilas PJ. Determinants of gastroesophageal junction incompetence: hiatal hernia, lower esophageal sphincter, or both? Ann Intern Med 1992;1 17:977-82

9 Field SK. A critical review of the studies of the effects of simulated or real gastroesophageal reflux on pulmonary function in asthmatic adults. Chest 1999; 115:848-56.

10 Ronkainen J, Aro P, Storskrubb T, et al. Gastro-oesophageal reflux symptoms and health-related quality of life in the adult general population - the Kalixanda study. Aliment Pharmacol Ther 2006;23:1725-33.

11 Dent J, El-Serag HB, Wallander MA, et al. Epidemiology of gastro-oesophageal reflux disease: a systematic review. Gut 2005;54:710-17.

12 Vaezi MF, Schroeder PL, Richter JE. Reproducibility of proximal probe $\mathrm{pH}$ parameters in 24-hour ambulatory esophageal $\mathrm{pH}$ monitoring. Am J Gastroenterol 1997;92:825-9.

13 Bhat YM, McGrath KM, Bielefeldt K. Wireless esophageal pH monitoring: new technique means new questions. J Clin Gastroenterol 2006;40:116-21.

14 Ronkainen J, Aro P, Storskrubb T, et al. High prevalence of gastroesophageal reflux symptoms and esophagitis with or without symptoms in the general adult Swedish population: a Kalixanda study report. Scand J Gastroenterol 2005:40:275-85

15 Zagari RM, Pozzato P, Damian S, et al. Relationship between gastroesophageal reflux symptoms and esophagitis in the general population: results from the Loiano-Monghidoro study. Gastroenterology 2006;130:T1018,

16 Thomson $A B$, Barkun AN, Armstrong D, et al. The prevalence of clinically significant endoscopic findings in primary care patients with uninvestigated dyspepsia: the Canadian Adult Dyspepsia Empiric Treatment-Prompt Endoscopy (CADET-PE) study. Aliment Pharmacol Ther 2003;17:1481-91.

17 Cropp GJA, Bernstein IL, Boushey HA. Guidelines for bronchial inhalation challenges with pharmacologic and antigenic agents. Am Thorac Soc Bull 1980;6:11-19.

18 Higgins JP, Thompson SG, Deeks JJ, et al. Measuring inconsistency in metaanalyses. BMJ 2003:327:557-60.

19 Peters JL, Sutton AJ, Jones DR, et al. Comparison of two methods to detect publication bias in meta-analysis. JAMA 2006;295:676-80.

20 Ruigomez A, Garcia Rodriguez LA, Wallander MA, et al. Gastroesophageal reflux disease and asthma: a longitudinal study in UK general practice. Chest 2005; 128:85-93

21 Gatto G, Peri V, Cuttitta G, et al. Gastroesophageal reflux symptoms are more frequent in patients with severe asthma. Gastroenterol Int 2000;13:139-42.

22 Field SK, Underwood M, Brant R, et al. Prevalence of gastroesophageal reflux symptoms in asthma. Chest 1996;109:316-22.

23 Al-Asoom L, Al-Rubaish AM, El-Munshid HA, et al. Gastroesophageal reflux in bronchial asthma patients. A clinical note. Saudi Med J 2003;24:1364-9.

24 Leggett JJ, Johnston BT, Mills $M$, et al. Prevalence of gastroesophageal reflux in difficult asthma: relationship to asthma outcome. Chest 2005;127:1227-31.

25 Suzuki J, Sasaki K, Adachi T, et al. [A study of gastroesophageal reflux by 24hour esophageal $\mathrm{pH}$ monitoring in patients with bronchial asthma] (in Japanese). Nippon Shokakibyo Gakkai Zasshi 1997;94:519-25.

26 Vincent D, Cohen-Jonathan AM, Leport J, et al. Gastro-oesophageal reflux prevalence and relationship with bronchial reactivity in asthma. Eur Respir J 1997; 10:2255-9.

27 Khoshbaten M. Gastro-esophageal reflux disease in northwestern Tabriz, Iran Indian J Gastroenterol 2003;22:138-9.

28 Carmona-Sanchez R, Valdovinos-Diaz MA, Facha MT, et al. [Hiatal hernia in asthmatic patients: prevalence and its association with gastroesophageal reflux] (in Spanish). Rev Invest Clin 1999;51:215-20.
29 Sontag SJ, O'Connell S, Miller TQ, et al. Asthmatics have more nocturnal gasping and reflux symptoms than nonasthmatics, and they are related to bedtime eating. Am J Gastroenterol 2004;99:789-96.

30 Sontag SJ, O'Connell S, Khandelwal S, et al. Most asthmatics have gastroesophageal reflux with or without bronchodilator therapy. Gastroenterology 1990:99:613-20.

31 Avidan B, Sonnenberg A, Schnell TG, et al. Temporal associations between coughing or wheezing and acid reflux in asthmatics. Gut 2001;49:767-72.

32 Sontag SJ, Schnell TG, Miller TQ, et al. Prevalence of oesophagitis in asthmatics. Gut 1992;33:872-6.

33 El-Serag HB, Sonnenberg A. Comorbid occurrence of laryngeal or pulmonary disease with esophagitis in United States military veterans. Gastroenterology 1997;113:755-60.

34 Compte L, Garrigues V, Perpina M, et al. Prevalence of gastroesophageal reflux in asthma. J Asthma 2000;37:175-82.

35 Kiljander TO, Laitinen JO. The prevalence of gastroesophageal reflux disease in adult asthmatics. Chest 2004;126:1490-4.

36 Shimizu Y, Dobashi K, Kobayashi S, et al. High prevalence of gastroesophageal reflux disease with minimal mucosal change in asthmatic patients. Tohoku J Exp Med 2006;209:329-36.

37 Perrin-Fayolle M, Bel A, Kofman J, et al. [Asthma and gastro-esophageal reflux. Results of a survey over 150 cases] (in French). Poumon Coeur 1980;36:225-30.

38 Luo JY. A study on the morphologic and dynamics of abnormality of the esophagus and gastroesophageal reflux in patients with asthma. Zhonghua jie he he hu xi za zhi = Zhonghua jiehe he huxi zazhi (Chinese J Tuberc Respir Dis) $1989 ; 12: 135-7,90$.

39 Harding SM, Guzzo MR, Richter JE. 24-h Esophageal pH testing in asthmatics: respiratory symptom correlation with esophageal acid events. Chest 1999:115:654-9

40 Nakase $\mathrm{H}$, Itani T, Mimura J, et al. Relationship between asthma and gastrooesophageal reflux: significance of endoscopic grade of reflux oesophagitis in adult asthmatics. J Gastroenterol Hepatol 1999;14:715-22.

41 Harding SM, Guzzo MR, Richter JE. The prevalence of gastroesophageal reflux in asthma patients without reflux symptoms. Am J Respir Crit Care Med 2000;162:34-9.

42 Mogica Martinez MD, Paredes Cruz E, Tenorio Pastrana MA, et al. [Prevalence of hiatal hernia and chronic esophagitis in adult asthmatic patients] (in Spanish) Rev Alerg Mex 2001;48:145-50.

43 Heaney LG, Conway E, Kelly C, et al. Predictors of therapy resistant asthma: outcome of a systematic evaluation protocol. Thorax 2003;58:561-6.

44 Liou A, Grubb JR, Schechtman KB, et al. Causative and contributive factors to asthma severity and patterns of medication use in patients seeking specialized asthma care. Chest 2003;124:1781-8.

45 Bochenska-Marciniak M, Gorski P. [Prevalence of gastroesophageal reflux disease in patients with bronchial asthma] (in Polish). Pol Merkuriusz Lek 2004; 16:527-31.

46 Carlo C, Anna F, Alessandra A, et al. Asthma and gastroesophageal reflux disease: effect of long-term pantoprazole therapy. World J Gastroenterol 2005;11:7657-60.

47 Gopal B, Singhal P, Gaur SN. Gastroesophageal reflux disease in bronchial asthma and the response to omeprazole. Asian Pac J Allergy Immunol 2005;23:29-34.

48 Chunlertrith K, Boonsawat W, Zaeoue U. Prevalence of gastroesophageal reflux symptoms in asthma patients at Srinagarind Hospital. J Med Assoc Thai 2005:88:668-71.

49 Kiljander TO, Salomaa ER, Hietanen EK, et al. Gastroesophageal reflux in asthmatics: a double-blind, placebo-controlled crossover study with omeprazole. Chest 1999; 1 16:1257-64.

50 Perpina $M$, Ponce J, Marco V, et al. The prevalence of asymptomatic gastroesophageal reflux in bronchial asthma and in non-asthmatic individuals. Eur J Respir Dis 1983;64:582-7.

51 Ducolone A, Vandevenne A, Jouin H, et al. Gastroesophageal reflux in patients with asthma and chronic bronchitis. Am Rev Respir Dis 1987;135:327-32.

52 Ekstrom T, Tibbling L. Gastro-oesophageal reflux and nocturnal asthma. Eur Respir J 1988;1:636-8.

53 Nagel RA, Brown P, Perks WH, et al. Ambulatory pH monitoring of gastrooesophageal reflux in "morning dipper" asthmatics. BMJ 1988;297:1371-3.

54 Giudicelli R, Dupin B, Surpas P, et al. [Gastroesophageal reflux and respiratory manifestations: diagnostic approach, therapeutic indications and results] (in French). Ann Chir 1990;44:552-4

55 DeMeester TR, Bonavina $\mathrm{L}$, lascone $\mathrm{C}$, et al. Chronic respiratory symptoms and occult gastroesophageal reflux. A prospective clinical study and results of surgical therapy. Ann Surg 1990;21 1:337-45.

56 Larrain A, Carrasco E, Galleguillos F, et al. Medical and surgical treatment of nonallergic asthma associated with gastroesophageal reflux. Chest $1991 ; 99: 1330-5$

57 Herve P, Escourrou P, Salmeron S, et al. [Risk factors for gastroesophageal reflux in chronic asthma] (in French). Rev Mal Respir 1993;10:527-30.

58 Gastal OL, Castell JA, Castell DO. Frequency and site of gastroesophageal reflux in patients with chest symptoms. Studies using proximal and distal $\mathrm{pH}$ monitoring. Chest 1994;106:1793-6.

59 Schnatz PF, Castell JA, Castell DO. Pulmonary symptoms associated with gastroesophageal reflux: use of ambulatory $\mathrm{pH}$ monitoring to diagnose and to direct therapy. Am J Gastroenterol 1996;91:1715-18.

60 Suh JK, Kwang Ho In, So Ra Lee, et al. Gastro-esophageal reflux in asthmatic patients. Tuberc Respir Dis 1997;44:836-43.

61 Campo S, Morini S, Re MA, et al. Esophageal dysmotility and gastroesophageal reflux in intrinsic asthma. Dig Dis Sci 1997;42:1184-8. 
62 Dal Negro R, Pomari C, Micheletto C, et al. Prevalence of gastro-oesophageal reflux in asthmatics: an Italian study. Ital J Gastroenterol Hepatol 1999:31:371-5.

63 Garcia-Compean D, Gonzalez MV, Galindo G, et al. Prevalence of gastroesophageal reflux disease in patients with extraesophageal symptoms referred from otolaryngology, allergy, and cardiology practices: a prospective study. Dig Dis 2000;18:178-82.

64 Oldigs M. [pH-Testing-experience in clinical practice in a pulmonary division] (in French). Pneumologie 2004;58:479-82.

65 Paleev NR, Isakov VA, Chereiskaia NK, et al. [Gastroesophageal reflux disease and respiratory apparatus pathology: the evidence of interrelation and unsolved problems] (in Russian). Vestn Ross Akad Med Nauk 2005:3-7.

66 Hsu JY, Lien HC, Chang CS, et al. Abnormal acid reflux in asthmatic patients in a region with low GERD prevalence. J Gastroenterol 2005;40:1 1-15.

67 Sami K, Lilia Z, Samira M, et al. Findings of 24-hour esophageal pH monitoring in patients with respiratory and otorhinolaryngologic manifestations of gastroesophageal reflux disease. Tunisie Medicale 2006;84:165-9.

68 Wong $\mathrm{CH}$, Chua CJ, Liam CK, et al. Gastro-oesophageal reflux disease in "difficult-to-control" asthma: prevalence and response to treatment with acid suppressive therapy. Aliment Pharmacol Ther 2006;23:1321-7.

69 Kiellen G, Brundin A, Tibbling L, et al. Oesophageal function in asthmatics. Eur J Respir Dis 1981;62:87-94.

70 Mays EE. Intrinsic asthma in adults. Association with gastroesophageal reflux. JAMA 1976;236:2626-8

71 Diez Gomez ML, Rubio Sotes M, Ortega Nunez A. Relation of hiatal hernia and respiratory tract pathology. Revista Clin Esp 1979;154:221-3.

72 Ben-Noun L. Characteristics of comorbidity in adult asthma. Public Health Rev 2001;29:49-61.

73 Locke GR III, Talley NJ, Fett SL, et al. Prevalence and clinical spectrum of gastroesophageal reflux: a population-based study in Olmsted County, Minnesota. Gastroenterology 1997;112:1448-56.

74 Ruhl CE, Sonnenberg A, Everhart JE. Hospitalization with respiratory disease following hiatal hernia and reflux esophagitis in a prospective, population-based study. Ann Epidemiol 2001;11:477-83.

75 Gislason T, Janson C, Vermeire P, et al. Respiratory symptoms and nocturnal gastroesophageal reflux: a population-based study of young adults in three European countries. Chest 2002;121:158-63.
76 Jaspersen D, Kulig M, Labenz J, et al. Prevalence of extra-oesophageal manifestations in gastro-oesophageal reflux disease: an analysis based on the ProGERD Study. Aliment Pharmacol Ther 2003;17:1515-20.

77 Wang JH, Luo JY, Dong L, et al. Epidemiology of gastroesophageal reflux disease: a general population-based study in $\mathrm{Xi}^{\prime}$ an of Northwest China. World J Gastroenterol 2004;10:1647-51.

78 Cho YS, Choi MG, Jeong JJ, et al. Prevalence and clinical spectrum of gastroesophageal reflux: a population-based study in Asan-si, Korea. Am J Gastroenterol 2005; 100:747-53.

79 Nordenstedt $\mathbf{H}$, Nilsson $M$, Johansson $\mathrm{S}$, et al. The relation between gastroesophageal reflux and respiratory symptoms in a population-based study: the Nord-Trondelag health survey. Chest 2006;129:1051-6.

80 Rey E, Elola-Olaso CM, Rodriguez-Artalejo F, et al. Prevalence of atypical symptoms and their association with typical symptoms of gastroesophageal reflux in Spain. Eur J Gastroenterol Hepatol 2006;18:969-75.

81 Bagnato GF, Gulli S, Giacobbe O, et al. Bronchial hyperresponsiveness in subjects with gastroesophageal reflux. Respiration 2000;67:507-9.

82 Riccioni G, Della Vecchia R, Menna V, et al. Prevalence of bronchial asthma in patients with endoscopically-documented esophagitis. Ann Clin Lab Sci 2004;34:94-8.

83 Roka R, Rosztoczy A, Izbeki F, et al. Prevalence of respiratory symptoms and diseases associated with gastroesophageal reflux disease. Digestion 2005:71:92-6

84 Li ZS, Xu XR, Zou DW, et al. [A study of extraesophageal presentations in gastroesophageal reflux disease] (in Chinese). Zhonghua Nei Ke Za Zhi 2006;45:13-16.

85 Mishima I, Adachi K, Arima N, et al Prevalence of endoscopically negative and positive gastroesophageal reflux disease in the Japanese. Scand J Gastroenterol 2005;40:1005-9

86 Sontag SJ. Why do the published data fail to clarify the relationship between gastroesophageal reflux and asthma? Am J Med 2000;108(Suppl 4a): 159S-69S.

87 Gibson PG, Henry RL, Coughlan JL. Gastro-oesophageal reflux treatment for asthma in adults and children. Cochrane Review. Issue 3. Oxford: update Software, 2002. Available: http://www.cochrane.org/reviews (accessed September 2004).

88 Barnes N. Most difficult asthma originates primarily in adult life. Paediatr Respir Rev 2006;7:141-4.

\section{EDITOR'S QUIZ: GI SNAPSHOT}

\section{A rare complication of peptic ulcer disease}

\section{Clinical presentation}

A 67-year-old Caucasian retired miner was referred by his general practitioner for an open access gastroscopy to evaluate dyspepsia of 6 months' duration. There were no associated "alarm symptoms", comorbidities, past history of similar symptoms or gastroscopy. His only drug, ranitidine $150 \mathrm{mg}$ twice daily, recently prescribed by his general practitioner, partially relieved his symptoms. He was an ex-smoker and drank alcohol in moderation. Gastroscopy in July 2003 showed findings in the antral area (fig l).

\section{Questions}

What are the findings in the figure?

What is the diagnosis?

See page 1677 for answers

M Srinivas, P Basumani Department of Gastroenterology, Rotherham Hospitals NHS Foundation Trust, UK

Correspondence to: Dr P Basumani, Level D, Rotherham General Hospital, Moorgate Road, Rotherham S60 2UD, UK; drsrinivasm@hotmail.com

doi: 10.1136/gut.2006.105304

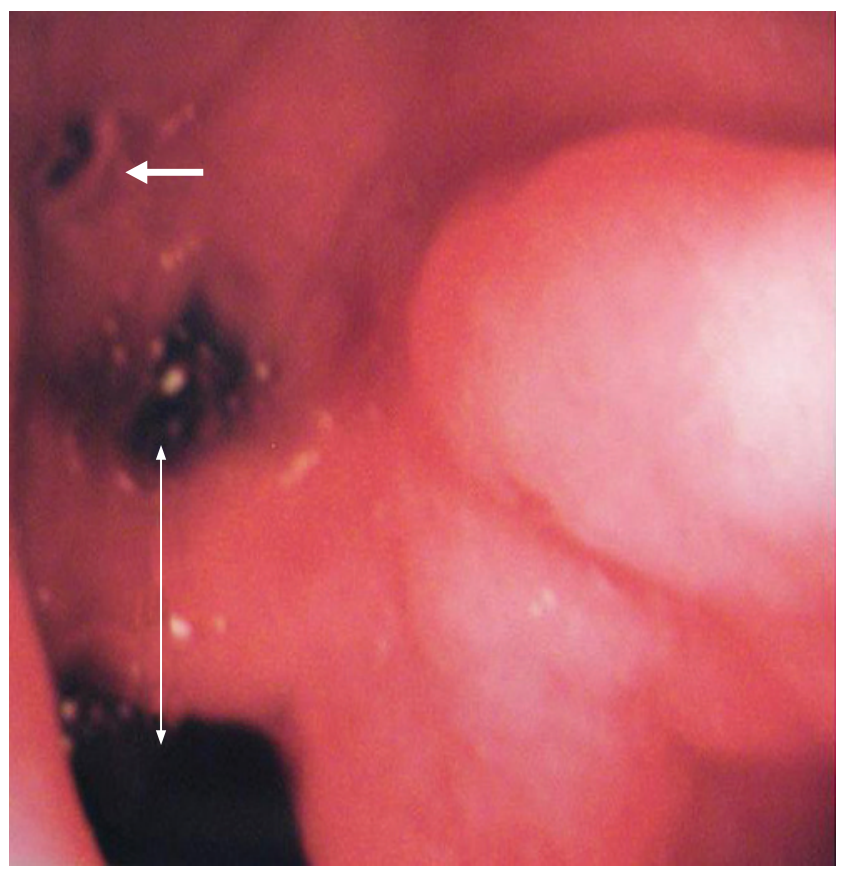

Figure 1 Endoscopic appearance of gastric antrum at initial gastroscopy. 